\title{
Changes in Chemical Constituents and Overall Acceptability of Aonla-Papaya Jam and Chutney during Storage
}

\author{
Sachin, Rakesh Gehlot, Saleem Siddiqui, Rekha, Anju Kumari and Rattan Singh* \\ Centre of Food Science and Technology \\ CCS Haryana Agricultural University, Hisar-125 004, Haryana, India \\ *Corresponding author
}

\section{A B S T R A C T}

\begin{tabular}{l} 
K e y w o r d s \\
Aonla, Papaya, \\
Blends, Jam, \\
Chutney, Chemical \\
constituents, \\
Overall \\
acceptability, \\
Storage \\
\hline Article Info \\
$\begin{array}{l}\text { Accepted: } \\
\text { 16 February } 2018 \\
\text { Available Online: } \\
\text { 10 March } 2018\end{array}$ \\
\hline
\end{tabular}

\section{Introduction}

Fruits and its value added products are important supplements to human diet due to presence of all the vital components required for normal growth and development of the human body. Blending of pulp from different fruits is practised to overcome the high cost of some exotic fruit product scarcity or seasonal availability, balancing of strong or bland flavours, high acidity, astringency and bitterness, and improving total soluble solids, colour and appearance, taste and overall acceptability. Nutritional and phytochemical properties can also be increased by blending pulps or juices, which offer to adjust sugar/acid ratios and compensate undesirable consistency. Aonla is used in Ayurvedic and Unani systems of Indian medicines. This fruit is acrid, cooling, refrigerant, diuretic and laxative. It is useful in anaemia, artherosclerosis, cough, diarrhoea, dysentery, dyspepsia, haemorrhages, leucorrhoea and jaundice. It possesses antibacterial, anticarcinogenic, antioxidative, antipyretic, antitumour, antiviral, cardiotonic and expectorant activities. The fruit is a rich source of ascorbic acid. The stability of 
ascorbic acid and presence of astringency in anola fruit is due to the presence of polyphenols and leucoanthocyanins. It is not consumed much as fresh fruit due highly acidic and astringent taste. Therefore, it is necessary to convert aonla pulp into certain value added food products for consumption. Several value added products like ready-toserve drink, nectar, squash, syrup, murabba, candy, pickles, jam, sauce, chutney, chayvanprash and triphala have been developed from this acrid fruit.

Papaya fruits are available throughout the year in India. The fruits are rich in nutrients, especially carotene, which is converted to vitamin A in human body. Vitamin A prevents blindness in children. Moreover, papaya has many medicinial properties, which cure a number of diseases. Some fruits, although, rich in nutrients but are not acceptable due to high acidity, poor taste or flavour, can be blended with other fruits to improve its acceptability and make use of available nutrients. Keeping in view the nutritional and functional attributes of aonla and papaya, the research work was planned to standardize appropriate combination of aonlapapaya blends for preparation of jam and chutney, and to evaluate storage quality of blended products.

\section{Materials and Methods}

The present investigation was carried out in Centre of Food Science and Technology, CCS HAU, Hisar during 2015-16. Mature aonla fruits of cv. Chakaiya were procured from local orchard, Hisar and papaya fruits were procured from local market, Hisar. Aonla fruits were washed thoroughly in running water, blanched in $2 \%$ brine $+2 \%$ alum + $0.2 \%$ potassium metabisulphite solution for 4 to 5 mintues. Aonla segments were separated from its stone and grated in a food processor. Aonla pulp was then blended with equal quantity of water (1L water for one $\mathrm{kg}$ grated pulp) in a mixer. Sodium benzoate $(1 \mathrm{~g} / \mathrm{kg}$ pulp) was mixed with the pulp. It was then packed in polypropylene jars and stored in deep freezer.

Papaya fruits were washed thoroughly in running water, peeled off and cut into halves. The halves were cut into thin slices after removal of seeds and white portion. The fruit slices were then made into fine pulp by blending it in a mixer. Papaya pulp was mixed with sodium benzoate @ 1 g/kg pulp, packed in polypropylene jars and stored in deep freezer.

Aonla and papaya pulp were blended in 100:0, 80:20, 60:40, 40:60, 20:80 and 0:100 ratio. For preparing jam, one $\mathrm{kg}$ pulp was cooked after mixing 700 to $800 \mathrm{~g}$ sugar, 0 to 5 $\mathrm{g}$ citric acid and 0 to $2 \mathrm{~g}$ pectin for different aonla-papaya blends. Jam was filled hot in $150 \mathrm{~g}$ capacity sterilized glass bottles, screw capped properly, cooled in air, labelled and stored at room temperature for three months (Fig. 1).

Chutney was prepared by cooking $1 \mathrm{~kg}$ pulp with 500 to $800 \mathrm{~g}$ sugar and 0 to $4 \mathrm{~g}$ citric acid (as per blends), $200 \mathrm{~g}$ onion paste, $20 \mathrm{~g}$ ginger paste, $10 \mathrm{~g}$ garlic paste, $3 \mathrm{~g}$ red chilli powder, $30 \mathrm{~g}$ salt, $8 \mathrm{~g}$ hot spice mix, 0 to $2 \mathrm{~g}$ pectin (as per blends) and $5 \mathrm{ml}$ glacial acetic acid. Chutney was filled hot in $150 \mathrm{~g}$ capacity sterilized glass bottles, screw capped properly, cooled in air, labelled and stored at room temperature for three months (Fig. 2).

Aonla-papaya jam and chutney were analyzed for changes in chemical constituents and overall acceptability at monthly interval during three months storage. Total and reducing sugars were estimated by the method of Hulme and Narain (1931). Acidity, ascorbic acid, total carotenoids and browning were analyzed by methods of Ranganna 
(2014). Total phenols were estimated by the method of Amorium et al., (1997). The overall acceptability of aonla-papaya jam and chutney was based on mean score obtained for all the sensory characters i.e., colour and appearance, flavour, texture, taste and mouthfeel. The characters with mean score of 6 and above out of 9 were considered acceptable (Ranganna, 2014). The treatments were replicated thrice and the data were analyzed statistically using completely randomized design. The critical difference value at 5 per cent level was used for making comparison among different treatments during storage period.

\section{Results and Discussion}

The total and reducing sugars of aonla-papaya jam and chutney increased significantly with increase in storage duration, which might be due to hydrolysis of polysaccharides and inversion of non-reducing sugar to reducing sugars. These findings are in agreement with the earlier workers of Reddy and Chikkasubbanna (2009) in amla jam and Gupta (2000) in sweet papaya chutney.

Acidity decreased significantly in aonlapapaya jam and chutney during three months storage. It might be due to hydrolysis of polysaccharides and non-reducing sugar, where acid is utilized for converting these into hexose sugars (reducing sugars) or complexing in the presence of metal ions.

These findings are in conformity with those of Reddy and Chikkasubbanna (2009) in amla jam.

Ascorbic acid content in aonla-papaya jam and chutney decreased significantly during the entire storage period of three months, which was probably due to the fact that ascorbic acid is sensitive to oxygen, light, enzymatic and non-enzymatic catalyst heat. It has also been observed by Singh and Singh (2014) in aonla chutney and Mazur et al., (2014) in red raspberry jam.

Total carotenoids also decreased significantly in aonla-papaya jam and chutney during three months storage period. This might be due to auto-oxidation of $\beta$-carotene, leading to loss of total carotenoids and due to its highly unsaturated chemical structure, which made the constituent very susceptible to thermal degradation and oxidation. The results are in accordance with those of Saravanan et al., (2004) in papaya jam and Teangpook and Paosantong (2013) in low sucrose lime juice papaya jam.

There was also significant decrease in total phenols of aonla-papaya jam and chutney during storage. Total phenols are easily volatile and oxidized, hence, its content decreased in the samples regardless of exposure to light or darkness. Moreover, cell structure disrupted during processing and the materials became prone to non-enzymatic oxidation, which could also be one of the major causes for loss in total phenols of the products. Similar decrease in total phenols was also reported by Shivani et al., (2008) in jamun jam and chutney.

There was significant increase in browning of aonla-papaya jam and chutney during storage. This might be due to condensation of tannins into brown pigments and inversion of nonreducing to reducing sugars, which participated in the maillard browning. Similar increase in browning was also reported by Verma and Chopra (2010) in aonla-mango mixed fruit slab.

Jam and chutney prepared from pure papaya pulp had maximum overall acceptability ( 8.48 and 8.05) followed by jam and chutney prepared from 40 aonla:60 papaya blend $(8.25$ and 7.85). 
Fig.1 Flow sheet for preparation of aonla-papaya jam

\author{
Aonla-papaya blends \\ $\downarrow$ \\ Addition of sugar \\ $\downarrow$ \\ Cooking \\ (occasional stirring) \\ $\downarrow$ \\ Addition of citric acid \\ $\downarrow$ \\ Cooking until $60 \%$ TSS \\ $\downarrow$ \\ Mixing of pectin \\ after dissolving in lukewarm water \\ Cooking until end point \\ (68\% TSS) \\ $\downarrow$ \\ Filling hot in sterilized glass bottles \\ (150 g capacity) \\ $\downarrow$ \\ Sealing with cap \\ $\downarrow$ \\ Cooling in air \\ $\downarrow$ \\ Labeling \\ $\downarrow$ \\ Storing at room temperature
}

Fig.2 Flow sheet for preparation of aonla-papaya chutney

Aonla-papaya blends

$\downarrow$

Addition of sugar

$\downarrow$

Cooking with occasional stirring

$\downarrow$

Mixing ingredients

(onion paste, ginger paste, garlic paste, citric acid and red chilli powder)

$\downarrow$

Cooking until 50\% TSS

$\downarrow$

Mixing pectin dissolved in lukewarm water

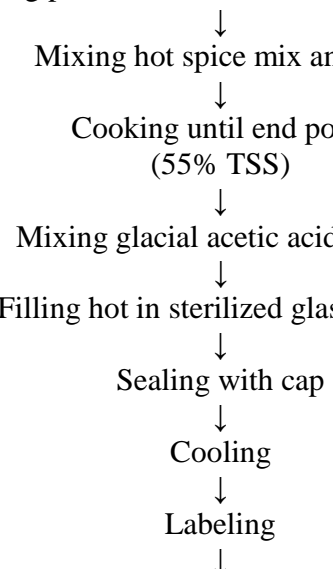

Storing at room temperature 
Table.1 Changes in chemical constituents and overall acceptability of aonla-papaya jam during storage

\begin{tabular}{|c|c|c|c|c|c|c|c|c|c|}
\hline $\begin{array}{c}\text { Treatments* } \\
\text { Aonla:Papaya }\end{array}$ & $\begin{array}{c}\text { Storage } \\
\text { period } \\
\text { (months) }\end{array}$ & $\begin{array}{l}\text { Total } \\
\text { sugars } \\
\%\end{array}$ & $\begin{array}{c}\text { Reducing } \\
\text { sugars } \\
(\%)\end{array}$ & $\begin{array}{c}\text { Acidity } \\
(\%)\end{array}$ & $\begin{array}{c}\text { Ascorbic } \\
\text { acid } \\
(\mathbf{m g} / 100 \mathrm{~g})\end{array}$ & $\begin{array}{c}\text { Total } \\
\text { carotenoids } \\
(\mathrm{mg} / 100 \mathrm{~g})\end{array}$ & $\begin{array}{c}\text { Total } \\
\text { phenols } \\
(\mathrm{mg} / 100 \mathrm{~g})\end{array}$ & $\begin{array}{c}\text { Browning } \\
\text { (440nm) }\end{array}$ & $\begin{array}{c}\text { Overall } \\
\text { acceptability } \\
\text { (score out of 9) }\end{array}$ \\
\hline \multirow[t]{4}{*}{ 100:0 } & $\mathbf{0}$ & 58.15 & 30.28 & 0.86 & 194 & 0.28 & 0.66 & 0.14 & 7.68 \\
\hline & 1 & 60.32 & 31.03 & 0.82 & 164 & 0.27 & 0.63 & 0.15 & 7.32 \\
\hline & 2 & 61.73 & 31.76 & 0.80 & 155 & 0.26 & 0.60 & 0.17 & 7.12 \\
\hline & 3 & 61.87 & 34.03 & 0.75 & 139 & 0.25 & 0.54 & 0.18 & 6.84 \\
\hline \multirow[t]{4}{*}{$80: 20$} & 0 & 57.41 & 29.20 & 0.81 & 171 & 0.91 & 0.64 & 0.13 & 7.90 \\
\hline & 1 & 58.44 & 30.40 & 0.75 & 143 & 0.89 & 0.60 & 0.14 & 7.40 \\
\hline & 2 & 59.32 & 31.19 & 0.74 & 135 & 0.83 & 0.56 & 0.16 & 7.16 \\
\hline & 3 & 60.73 & 32.12 & 0.70 & 122 & 0.82 & 0.52 & 0.17 & 6.82 \\
\hline \multirow[t]{4}{*}{$60: 40$} & 0 & 56.24 & 25.41 & 0.81 & 158 & 1.53 & 0.61 & 0.12 & 8.06 \\
\hline & 1 & 57.76 & 26.07 & 0.77 & 133 & 1.50 & 0.59 & 0.14 & 7.68 \\
\hline & 2 & 58.53 & 27.04 & 0.73 & 127 & 1.44 & 0.56 & 0.15 & 7.44 \\
\hline & 3 & 59.96 & 27.94 & 0.70 & 116 & 1.40 & 0.54 & 0.17 & 7.20 \\
\hline \multirow[t]{4}{*}{ 40:60 } & 0 & 55.16 & 24.52 & 0.77 & 98 & 1.72 & 0.59 & 0.11 & 8.64 \\
\hline & 1 & 56.60 & 24.73 & 0.73 & 82 & 1.67 & 0.57 & 0.13 & 8.44 \\
\hline & 2 & 57.28 & 26.68 & 0.70 & 78 & 1.62 & 0.55 & 0.14 & 8.20 \\
\hline & 3 & 58.36 & 27.58 & 0.67 & 71 & 1.57 & 0.53 & 0.15 & 7.72 \\
\hline \multirow[t]{4}{*}{$20: 80$} & 0 & 51.96 & 23.94 & 0.77 & 84 & 2.33 & 0.56 & 0.10 & 8.64 \\
\hline & 1 & 52.36 & 24.72 & 0.73 & 69 & 2.26 & 0.55 & 0.12 & 8.40 \\
\hline & 2 & 53.92 & 26.14 & 0.70 & 64 & 2.18 & 0.54 & 0.13 & 8.12 \\
\hline & 3 & 55.24 & 27.22 & 0.68 & 60 & 2.12 & 0.52 & 0.14 & 7.76 \\
\hline \multirow[t]{4}{*}{$0: 100$} & 0 & 51.04 & 22.89 & 0.73 & 34 & 2.85 & 0.57 & 0.09 & 8.88 \\
\hline & 1 & 51.94 & 23.97 & 0.67 & 26 & 2.79 & 0.53 & 0.10 & 8.72 \\
\hline & 2 & 53.03 & 25.05 & 0.66 & 23 & 2.72 & 0.51 & 0.11 & 8.40 \\
\hline & 3 & 53.80 & 25.78 & 0.65 & 21 & 2.64 & 0.50 & 0.13 & 7.92 \\
\hline \multirow[t]{2}{*}{ CD at $5 \%$} & Treatment & 0.68 & 0.26 & 0.05 & 0.92 & 0.03 & 0.03 & 0.01 & 0.21 \\
\hline & Storage & 0.56 & 0.21 & 0.04 & 0.75 & 0.03 & 0.03 & 0.01 & 0.17 \\
\hline \multicolumn{2}{|c|}{ Treatment $\times$ Storage } & 1.37 & 0.52 & NS & 1.84 & NS & NS & 0.01 & NS \\
\hline
\end{tabular}

*Recipe - $1 \mathrm{~kg}$ blended pulp, 700 to $800 \mathrm{~g}$ sugar, 0 to $5 \mathrm{~g}$ citric acid and 0 to $2 \mathrm{~g}$ pectin; NS - Non-significant 
Table. 2 Changes in chemical constituents and overall acceptability of aonla-papaya chutney during storage

\begin{tabular}{|c|c|c|c|c|c|c|c|c|c|}
\hline $\begin{array}{c}\text { Treatments* } \\
\text { Aonla:Papaya }\end{array}$ & $\begin{array}{c}\text { Storage } \\
\text { period } \\
\text { (months) }\end{array}$ & $\begin{array}{c}\text { Total } \\
\text { sugars } \\
(\%)\end{array}$ & $\begin{array}{c}\text { Reducing } \\
\text { sugars } \\
(\%)\end{array}$ & $\begin{array}{c}\text { Acidity } \\
(\%)\end{array}$ & $\begin{array}{l}\text { Ascorbic } \\
\text { Icid (mg/10c } \\
\text { g) }\end{array}$ & $\begin{array}{c}\text { Total } \\
\text { carotenoids } \\
(\mathbf{m g} / 100 \mathrm{~g})\end{array}$ & $\begin{array}{c}\text { Total } \\
\text { phenols } \\
(\mathbf{m g} / \mathbf{1 0 0} \mathrm{g})\end{array}$ & $\begin{array}{c}\text { Browning } \\
(440 \mathrm{~nm})\end{array}$ & $\begin{array}{c}\text { Overall } \\
\text { acceptability } \\
\text { (score out of 9) }\end{array}$ \\
\hline \multirow[t]{4}{*}{ 100:0 } & 0 & 46.14 & 29.92 & 0.81 & 124 & 0.27 & 0.81 & 0.28 & 7.60 \\
\hline & 1 & 47.23 & 30.46 & 0.79 & 112 & 0.26 & 0.79 & 0.32 & 7.40 \\
\hline & 2 & 47.95 & 30.82 & 0.75 & 98 & 0.25 & 0.75 & 0.34 & 7.20 \\
\hline & 3 & 48.31 & 31.19 & 0.70 & 86 & 0.24 & 0.70 & 0.36 & 7.00 \\
\hline \multirow[t]{4}{*}{$80: 20$} & 0 & 43.61 & 28.85 & 0.73 & 110 & 0.88 & 0.73 & 0.26 & 8.00 \\
\hline & 1 & 44.70 & 29.20 & 0.70 & 99 & 0.86 & 0.70 & 0.30 & 7.60 \\
\hline & 2 & 45.78 & 29.92 & 0.66 & 87 & 0.85 & 0.66 & 0.31 & 7.20 \\
\hline & 3 & 46.87 & 30.65 & 0.62 & 79 & 0.83 & 0.62 & 0.34 & 7.00 \\
\hline \multirow[t]{4}{*}{$60: 40$} & 0 & 41.46 & 25.96 & 0.73 & 96 & 1.44 & 0.73 & 0.23 & 8.20 \\
\hline & 1 & 42.54 & 26.32 & 0.69 & 88 & 1.41 & 0.69 & 0.28 & 7.80 \\
\hline & 2 & 43.62 & 26.86 & 0.65 & 79 & 1.38 & 0.65 & 0.30 & 7.20 \\
\hline & 3 & 44.63 & 27.58 & 0.61 & 73 & 1.36 & 0.61 & 0.31 & 6.80 \\
\hline \multirow[t]{4}{*}{$40: 60$} & 0 & 37.86 & 24.46 & 0.68 & 81 & 1.99 & 0.68 & 0.17 & 8.40 \\
\hline & 1 & 39.29 & 25.24 & 0.61 & 75 & 1.96 & 0.61 & 0.19 & 8.00 \\
\hline & 2 & 40.37 & 25.86 & 0.57 & 69 & 1.92 & 0.57 & 0.24 & 7.60 \\
\hline & 3 & 41.40 & 26.32 & 0.53 & 64 & 1.88 & 0.53 & 0.26 & 7.40 \\
\hline \multirow[t]{4}{*}{$20: 80$} & 0 & 34.61 & 23.43 & 0.67 & 56 & 2.46 & 0.67 & 0.17 & 8.00 \\
\hline & 1 & 35.33 & 24.16 & 0.60 & 52 & 2.42 & 0.60 & 0.19 & 7.60 \\
\hline & 2 & 36.41 & 24.70 & 0.55 & 49 & 2.38 & 0.55 & 0.22 & 7.60 \\
\hline & 3 & 37.49 & 25.42 & 0.51 & 44 & 2.34 & 0.51 & 0.23 & 7.20 \\
\hline \multirow[t]{4}{*}{ 0:100 } & 0 & 33.53 & 22.89 & 0.60 & 28 & 3.01 & 0.60 & 0.14 & 8.60 \\
\hline & 1 & 34.61 & 23.43 & 0.56 & 25 & 2.95 & 0.56 & 0.16 & 8.20 \\
\hline & 2 & 36.05 & 23.80 & 0.48 & 24 & 2.89 & 0.48 & 0.17 & 7.80 \\
\hline & 3 & 36.77 & 24.52 & 0.42 & 20 & 2.84 & 0.42 & 0.18 & 7.60 \\
\hline \multirow[t]{2}{*}{ CD 5\% } & Treatment & 0.45 & 0.22 & 0.05 & 0.94 & 0.04 & 0.04 & 0.02 & 0.18 \\
\hline & Storage & 0.37 & 0.18 & 0.04 & 0.77 & 0.03 & 0.03 & 0.01 & 0.15 \\
\hline \multicolumn{2}{|c|}{ Treatment $\times$ Storage } & NS & NS & NS & 1.88 & NS & NS & NS & NS \\
\hline
\end{tabular}


Jam and chutney prepared from pure aonla pulp were found least acceptable (7.24 and 7.30) (Table 1 and 2). The overall acceptability of aonla-papaya jam and chutney decreased significantly during three months storage period. Similar results were reported by Reddy and Chikkasubbanna (2009) in amla jam and Mishra et al., (2011) in ready-to-eat amla chutney.

\section{References}

Amorium, H.V., Dougall, D.K. and Sharp, W.R. (1997) The effect of carbohydrate and nitrogen concentrations of phenol synthesis in plant scarlet rose cells grown in tissue culture. Physiologia Plantarum, 39, 91-95.

Gupta, G.K. (2000) Standardization of recipe for preparation of sweet papaya chutney. Indian Food Packer, 54(5), 115-117.

Hulme, A.C. and Narain, R. (1931) The ferricyanide method for determination of reducing sugars. A modification of Hagedom-Jensen-Hanes technique. Biochemistry Journal, 25(4), 1051-1061.

Mazur, S.P., Nes, A., Wold, B., Remberg, S.F., Martinsen, B.K. and Aaby, K. (2014) Effect of genotype and storage time on stability of colour, phenolic compounds and ascorbic acid in red raspberry (Rubus idaeus L.) jams. Acta Agriculturae Scandinavica, Section B Soil \& Plant Science, 64(5), 442-453.

Mishra, P., Verma, M., Mishra, V., Mishra, S. \& Rai, G.K. (2011) Studies on development of ready-to-eat amla
(Emblica officinalis) chutney and its preservation by using class one preservatives. American Journal of Food Technology, 6(3), 244-252.

Ranganna, S. (2014) "Handbook of Analysis and Quality Control for Fruit and Vegetable Products" (2 $2^{\text {nd }}$ Edn.). Tata McGraw Hills Publishing Co. Ltd., New Delhi.

Reddy, A.H. and Chikkasubbanna, V. (2009) Studies on the storage behaviour of amla jam. International Journal of Agricultural Sciences, 5(1), 55-59.

Saravanan, K., Godara, R.K., Goyal, R.K. and Sharma, R.K. (2004) Studies on the storage behaviour of papaya jam. Haryana Journal of Horticulture Sciences, 33 (3\&4), 218-220.

Shivani, Gehlot, R., Singh, R. \& Siddiqui, S. (2008) Changes in chemical constituents and overall acceptability of jamun jam and chutney during storage. Haryana Journal of Horticultural Sciences, 37(1), 60-63.

Singh, M.L. and Singh, I. (2014) Suitability of varieties for aonla chutney. International Journal of Home Science Extension and Communication Management, 1(1), 24-28.

Teangpook, C. and Paosantong, U. (2013). Production and shelf-life of low sucrose lime juice papaya jam. Pakistan Journal of Nutrition, 12(9), 870-878.

Verma, G. and Chopra, C.S. (2010) Preparation and preservation of AonlaMango Mixed Fruit Slab. Beverage \& Food World, 37(1), 60.

\section{How to cite this article:}

Sachin, Rakesh Gehlot, Saleem Siddiqui, Rekha, Anju Kumari and Rattan Singh. 2018. Changes in Chemical Constituents and Overall Acceptability of Aonla-Papaya Jam and Chutney during Storage. Int.J.Curr.Microbiol.App.Sci. 7(03): 2001-2007. doi: https://doi.org/10.20546/ijcmas.2018.703.235 